\title{
Phytotherapy of High Blood Pressure in Three Phytogeographic Regions of Cameroon
}

Nole Tsabang ${ }^{1 *}$, Clement G Yedjou ${ }^{2}$ and Paul B Tchounwou ${ }^{3}$

${ }^{1}$ Center for Research on Medicinal Plants and Traditional Medicine, Institute of Medical Research and Studies of Medicinal Plants (IMPM), Yaounde, Cameroon

${ }^{2}$ Cellomics and Toxicogenomics Research Laboratory, NIH-RCMI Center for Environmental Health, Jackson State University, Jackson, USA

${ }^{3}$ Molecular Toxicology Research Laboratory, NIH-Center for Environmental Health, College of Science, Engineering and Technology, Jackson State University, Jackson, Mississippi, USA

\begin{abstract}
Objective: High blood pressure is a public health challenge worldwide. According to World Health Organization, $30 \%$ of men and $50 \%$ of women 65 to 75 years old are suffering from high blood pressure. The number of hypertensive patients in the world will attain 1.56 billion of people, with $60 \%$ increase in prevalence. The incidence of high blood pressure increases with age, but nowadays, is being noticed an increasing incidence in young people. The sociocultural medicine may provide new solutions in the management of this pathology. Therefore this study was carried out to record and document plants used against high blood pressure in socio-cultural medicine for future drugs discovery worldwide.
\end{abstract}

Methods: An ethno botanical survey was realized between 2002 and 2016 to identify manifold plants used to fight against high blood pressure. This survey was carried out in three phytogeographic regions of Cameroon. Amongst people living in those regions, 1131 randomly screened interviewees distributed in 58 socio-cultural groups were involved in this study.

Results: This survey reveals that about $70 \%$ of interviewees don't know high blood pressure which is a symptomless disease. A total of 28 species of plants were recorded. These plants belong to 25 genera and 24 families. They were used to prepare 28 herbal remedies for the treatment of high blood pressure. In the morphological point of view about 10/28 (36\%) plants are herbs; $9 / 28(32 \%)$ plants are trees and $9 / 28(32 \%)$ plants are shrubs. Only $3 / 28$ plants (11\%) used including Allium sativum, Aloe barteri and Aloe buttneri) are cultivated. This means that the plants used in this study don't usually have some form of protection through cultivation which is encouraging in terms of their conservation.

Conclusion: The uncontrolled use of a hypotensive plants can provoke a fatal hypotension in hypertensive patients. Therefore the use of hypotensive plants needs to be controlled by physician or by a patient verification using a blood pressure monitor. Recorded species which will slow the high blood pressure will be used for the preparation of phytodrugs.

Keywords: Cameroon; Anti-hypertensive plants; Phytotheraphy; Phytogeographic areas

\section{Introduction}

High blood pressure is a multifactor disease, provoked by the association of the genetic predisposition and certain phenotypes like the sensitivity of the arterial blood pressure with sodium concentration, hypocalcaemia and a strong influence of the environment, according to the W.H.O. High blood pressure is manifested when the blood pressure values, measured many times in the occasion of at least two different consultations in four months are superior or equal to 140 $\mathrm{mmHg}$ for systolic and superior or equal to $90 \mathrm{mmHg}$ for diastolic. These parameters used to diagnose high blood pressure in occidental medicine are unknown in socio-cultural medicine. Traditional healers, mostly from the hinterland will indirectly control this disease by treating rather their observed and recognized symptoms and/or complications including nose bleeding, filling of the flies before the eyes, dizziness, insomnia, muscular and sexual weakness, edema, etc. The cost of the monthly treatment of non-complicated high blood pressure is $92.24 €$ per patient. The diet increases the financial charges of patients. Certain combinations of anti-hypertension's treatments, composed from pharmaceutical products and their cost such as Hexen 50 (21.13€), Lodoz $(15.88 €)$ are rare in rural zones or expensive for patients. Then the difficulties to get drugs can permit the appearance of redoubtable complications including left ventricular hypertrophy, occlusion of vessels in the heart (infarct) and in the brain (cerebral softness), strokes and kidney failure.
High blood pressure constitutes a public health problem in the World [1]. It is a chronic disorder much frequent in Cameroon [2]. In fact the prevalence of high blood pressure adjusted to the age is $16.6 \%$ and $12.6 \%$ in men and women respectively in urban population [2]. The victims, with number always in increase constitute a charge for families in Cameroon. They are condemned to dead, seeing their restriction of access to pharmaceutical drugs. But the populations, mostly of hinterland, distant away of urban areas which are well furnished in pharmaceutical products, have developed a wonderful experience on the uses of medicinal and alimentary plants. Occidental medicine has developed hypertensive drugs, but the progressive deterioration of the patients of blood pressure control by these drugs and the poverty in the

*Corresponding author: Nole Tsabang, Center for Research on Medicinal Plants and Traditional Medicine, Institute of Medical Research and Studies of Medicina Plants (IMPM), Yaounde, Cameroon, Tel: (237)77461631, (237)98301195; E-mail: tsabang2001@yahoo.fr, tsabang@hotmail.com

Received November 03, 2016; Accepted January 27, 2017; Published January 30, 2017

Citation: Tsabang N, Yedjou CG, Tchounwou PB (2017) Phytotherapy of High Blood Pressure in Three Phytogeographic Regions of Cameroon. Pharm Anal Acta 7: 530. doi: 10.4172/2153-2435.1000530

Copyright: @ 2017 Tsabang N, et al. This is an open-access article distributed under the terms of the Creative Commons Attribution License, which permits unrestricted use, distribution, and reproduction in any medium, provided the original author and source are credited. 
developing countries make the traditional medicine to be an alternative for the treatment [3]. Therefore this study was carrying out to record and document plants used in socio-cultural medicine for future drugs discovery worldwide.

\section{Methodology}

In order to collect manifold plants that can treat high blood pressure, an ethnobotanical survey was carried out in various socio-cultural groups [4] living in three big phytogeographic regions including coastal rain forests; continental rain forests and Sudano-Zambezian Region and Guinian savannahs zones (4:5). The ethnobotanical survey was carried out in these units, with interviewees selected in different tribes.

A total of 58 socio-cultural groups (composed by 16 in coastal rain forests phytogeographic region, 14 in continental rain forests phytogeographic region and 23 in Guinian and Sudano-Zambezian savannahs region) were explored during the interwiew. The fieldwork was conducted using semi structural questionnaire with different sections of plant species identification, ethnopharmacological detailed preparations, description of recipes, ethnomedical modes of administration, posology, duration of treatment, undesirable or secondary effects and toxic effects. The confirmation of the potential efficacy of some recorded antihypertensive plants was done using previous pharmacological studies. The plants and plant names (Scientific, English, and Vernacular), plant parts used, type of hypertension treated and photochemical principles of the plants $[5,6]$ and frequency of plants were recorded. The identification of samples plant species has been confirmed in National Herbarium of Cameroon and samples plants recorded were conserved in the Institute of Medical Research and Studies of Medicinal Plants.

\section{Results}

- All the recipes recorded are described in detail at the end in Table 1. The statistical analysis realized from this table revealed the following results:

- A total of 28 species of plants were recorded. These plants belong to 25 genera and 24 families. They were used to prepare 28 herbal remedies for the treatment of high blood pressure.

- In the morphological point of view about $10 / 28$ (36\%) plants are herbs; $9 / 28(32 \%)$ plants are trees and $9 / 28$ plants are (32\%). Only $3 / 28$ plants (11\%) used including Allium sativum, Aloe barteri and Aloe buttneri) are cultivated. This means that the plants used in this study don't have usually some form of protection through cultivation which is encouraging in terms of their conservation. Fifty-five percent (55\%) of the herbal remedies are prepared with plants belonging to the families of Apocynaceae, Caesalpiniaceae, Liliaceae, Mimosaceae, Rubiaceae, Rutaceae and Fabaceae. The

\begin{tabular}{|c|c|c|c|c|c|}
\hline \multirow{3}{*}{ Number } & \multicolumn{5}{|c|}{ Usual antihypertensive plants } \\
\hline & R1 & $\mathbf{R 2}$ & R3 & Total & $\begin{array}{l}\text { Plants with prevoius } \\
\text { hypotensive effect }\end{array}$ \\
\hline & 8 & 7 & 13 & 28 & 18 \\
\hline \multicolumn{6}{|c|}{$\begin{array}{c}\% \text { of usual antihypertensive plants with established hypotensive } \\
\text { effects: } 64 \%\end{array}$} \\
\hline
\end{tabular}

Table 1: Ethnopharmacological description of all herbal remedies according to phytogeographic regions The Table 1 presents the distribution of herbal remedies with precision on the morphology of the plants used, parts used, ethnopharmacological methods of preparation, administration route, dosages, frequencies of use, different types of herbal remedies recorded and duration of treatments. R1: Coastal rain forests region; R2: Continental rain forests region; R3: Guinean and Sudano-Zambezian Region and savannahs region. most frequent cited genera are Zanthoxylum, Musanga, Afzelia, Albizia, Voacanga and Hallea.

- For the parts of plants used the leaves $18 / 42$ (43\%) were the most important plant parts used in the preparation of the herbal remedies, following by the stem bark 14/42 (33\%).

- It is important to note that harvesting of leaves for treatment of high blood pressure will be less detrimental to populations of plants compared to roots, stem materials and whole plants, especially in this case where there is no sustainable harvesting strategy. The leaves of the plants should be used as an alternative if their chemical composition is not very different from that of the roots, stem materials or the whole plant.

- The most used plants are Moringa oleifera (280 repetitions), following by Aloe buettneri and Aloe barteri (208 repetitions each).

- Most of the herbal remedies were prepared by boiling in water or decoction $19 / 28(68 \%)$, following by infusion $5 / 28(18 \%)$, maceration $3 / 28(11 \%)$ and consumption $1 / 28(3 \%)$. This situation is not different from what has been reported in the treatment of malaria in Ghana [7-8] and in Budiope County of Uganda [9] and Msambweni District of Kenya [10]. Boiling of plant materials was also the main method of ethnopharmacological preparation of herbal remedies for the treatment of high blood pressure such as in Yaounde and its surroundings areas in the case of diabetes treatment [11].

- All the herbal remedies used in this study were administered orally. Dosage prescriptions were adapted approximately to a glassful (equivalent to $250 \mathrm{~mL}$ ) or half a glassful three times per day was respectively prescribed for adults and children. Treatment was supposed to be continued until recovery. The problems associated with dosage prescription in the use of herbal remedies for the treatment of malaria has been highlighted by a number of authors $[7,9]$. In this study we have try to resolve the problem by quantifying the amount of plants material used and the dosage.

- Traditional healers reported that their herbal remedies had no side effects. This is not verified because traditional healers do not follow up for the side effects of their remedies. Similar observations have been made in Ghana [8].

- There is no significant difference between trees, herbs and shrubs recorded.

\section{Discussion}

\section{Knowledge about high blood pressure and treatment practices}

Traditional healers interviewed, seemed to know high blood pressure through observation of some signs, symptoms and complications. Those included feeling of the flies before eyes (90\%), sexual weakness (70\%), muscular weakness (90\%), insomnia (95\%), dizziness (90\%), edema $(64 \%)$, hemiplegic paralysis $(12 \%)$, angina $(10 \%)$, nosebleeds or nose hemorrhage $(21 \%)$, severe headaches $(45 \%)$, severe anxiety $(30 \%)$ and shortness of breath (8\%). The percentage number of interviewees is indicated in brackets. The mode of transmission of the disease wasn't well known. Some interviewees know that high blood pressure is family disease. All the traditional healers interviewed used herbal remedies for the treatment of high blood pressure. The reasons for using herbal remedies were their availability and their cost-effective. It is important to note that herbal remedies were used for only curative purposes. So in 
Citation: Tsabang N, Yedjou CG, Tchounwou PB (2017) Phytotherapy of High Blood Pressure in Three Phytogeographic Regions of Cameroon. Pharm Anal Acta 7: 530. doi: 10.4172/2153-2435.1000530

Page 3 of 7

the management of high blood pressure herbal remedies were not used for prevention in tribes visited.

Comparison of ethnopharmacological uses with previous pharmacological studies (antihypertensive plant extracts and physiochemical constituent's activities)

The literature search showed that many antihypertensive plants were used to treat malaria in other parts of Africa. However, $12 \%$ of plants are documented for the treatment of high blood pressure in the literature search viewed [12-28]. The more important of these plants are Allium sativum, Hallea inermis and Hallea stipulosa. The phytochemical constituents of these plants have also been isolated. The phytochemical composition of medicinal plants is rarely constant, which may be an advantage over chemically homogeneous drugs controlling chronic disease such as high blood pressure. Nevertheless, knowledge of the pharmacological, phytochemical and toxicological properties of the herbal remedies used needs to be investigated in order to ensure the effective treatment for high blood pressure as well as its safety for people and the need to presents the active compounds in those plants as well as their antihypertensive activities (Table 1).

\section{Secondary high blood pressure}

The presences of one or several antihypertensive substances in plants of Table 1 which can treat the secondary high blood pressure (Table 1) confirm the use of these plants in socio-cultural medicine against high blood pressure.

\section{Essential high pressure}

Phyllanthus niruri is the only plant which can treat the essential high blood pressure (Table 1).

\section{Distribution of usual antihypertensive plants}

Usual antihypertensive plants were recorded with the aid from $30 \%$ traditional healers and other informants who know high blood pressure. Table 2 presents their distribution.

\section{Conclusion}

At the end of this study we realize that plants which can play an important role in the treatment of high blood pressure are effectively different between the three phytogeographic regions. According to this reason manifold plants and recipes were identified. The determination of the type of high blood pressure treated was necessary to optimize the effectiveness of plants used. The development of complications and the no mastering of the multiple causes of this affection make more difficult the action of herbal remedies. The traditional healers should imperatively oblige patients to confirm their high blood pressure state by taking at least two times their blood pressure in two different consultations in four weeks. This practice can help for an earlier diagnostic of patients. The knowledge of bioactive plants can favor a better management of patients and the improvement of the quality of socio-sanitary cares administered to patients. Amongst antihypertensive plants recorded Allium sativum (garlic) is able to reduce significantly the rate of cholesterol in the blood. This species is

\begin{tabular}{|c|c|c|c|c|c|c|c|c|c|}
\hline $\begin{array}{r}\text { SI } \\
\text { No }\end{array}$ & $\begin{array}{l}\text { Family, scientific and } \\
\text { English names }\end{array}$ & Vernacular names & $\begin{array}{l}\text { Plant part } \\
\text { (s) used }\end{array}$ & $\begin{array}{l}\text { Medicinal } \\
\text { Plants }\end{array}$ & $\begin{array}{l}\text { Principles and } \\
\text { activités }\end{array}$ & $\begin{array}{l}\text { Methods of } \\
\text { preparation }\end{array}$ & $\begin{array}{l}\text { Route of } \\
\text { administra } \\
\text { tion }\end{array}$ & $\begin{array}{l}\text { Posoloy, } \\
\text { duration of } \\
\text { treatment and } \\
\text { secondary } \\
\text { effects }\end{array}$ & FR \\
\hline \multicolumn{10}{|c|}{ Coastal rain forests region } \\
\hline 1 & $\begin{array}{c}\text { Menispermaceae } \\
\text { Jateorhiza macrantha } \\
\text { Herb }\end{array}$ & $\begin{array}{l}\text { Mbi (Bakola), Kolkoio } \\
\text { (Bakoun), }\end{array}$ & Young leaves & $\begin{array}{c}\text { Secondary } \\
\text { high blood } \\
\text { pressure }\end{array}$ & $\begin{array}{l}\text { Columbamine/ } \\
\text { hypotensive [14] }\end{array}$ & $\begin{array}{l}\text { Decoction of } 100 \mathrm{~g} \text { of } \\
\text { young leaves in } 3 \mathrm{~L} \\
\text { of water, for } 25 \mathrm{~min} .\end{array}$ & Oral & $\begin{array}{c}\text { Take } 250 \mathrm{~mL} \text { of } \\
\text { decoction three } \\
\text { times a day, for a } \\
\text { week. }\end{array}$ & 5 \\
\hline 2 & $\begin{array}{c}\text { Caesalpiniaceae } \\
\text { Afzelia bipindensis } \\
\text { English: Doussie Doussie } \\
\text { Rouge } \\
\text { Tree }\end{array}$ & $\begin{array}{c}\text { Common name Apa } \\
\text { Mbanga (Douala), Ndemba } \\
\text { (Bassa),Timi (Baka), Njoc } \\
\text { (Ewondo); }\end{array}$ & Fresh leaves & & & $\begin{array}{c}\text { Decoction of } 200 \mathrm{~g} \text { of } \\
\text { fresh leaves in } 3 \mathrm{~L} \text { of } \\
\text { water for } 15 \mathrm{mn}\end{array}$ & Oral & $\begin{array}{l}\text { Take } 250 \mathrm{~mL} \text { of } \\
\text { decoction } 3 \text { times } \\
\text { daily, for a week. }\end{array}$ & 6 \\
\hline 3 & $\begin{array}{c}\text { Apocynaceae } \\
\text { Voacanga thouarsii } \\
\text { English name: Wild frangipani } \\
\text { Small tree }\end{array}$ & Eyolla njongi (Douala) & Fresh bark & & & $\begin{array}{l}\text { Decoction of } 100 \mathrm{~g} \text { of } \\
\text { fresh bark, in } 3 \mathrm{~L} \text { of } \\
\text { water, for } 30 \mathrm{~min} .\end{array}$ & Oral & $\begin{array}{l}\text { Drink } 250 \mathrm{~mL} \text { of } \\
\text { decoction, } 3 \text { times } \\
\text { a day, for } 5 \text { days. }\end{array}$ & 18 \\
\hline 4 & $\begin{array}{c}\text { Urticaceae } \\
\text { Laportea ovalifolia } \\
\text { English name: Fowl nettle } \\
\text { Hawai' i woody nettle } \\
\text { Herb }\end{array}$ & $\begin{array}{c}\text { Tololi, Itoil (Oroko), Sasa } \\
\text { kola (Bassa), Sasangulu } \\
\text { (Pygmies), Kinhiemou } \\
\text { (Widekam), Kinshei (Banso), } \\
\text { Sisie (Bamiléke), Dandy } \\
\text { (Bagweri) }\end{array}$ & Aerial parts & & $\begin{array}{l}\text { saponins, tannins, and } \\
\text { phenolic compounds } \\
\text { for aqueous } \\
\text { extract and sugars, } \\
\text { saponins, } \\
\text { phenolic compounds, } \\
\text { Sterol, triterpens lipids, } \\
\text { alkaloids, and } \\
\text { Glycosides for } \\
\text { methanol/methylene } \\
\text { chloride extract [15]. }\end{array}$ & $\begin{array}{l}\text { Maceration of } 100 \mathrm{~g} \\
\text { of aerial parts in } 2 \mathrm{~L} \\
\text { of water. }\end{array}$ & Oral & $\begin{array}{c}\text { Drink } 250 \mathrm{~mL} \text { of } \\
\text { macerate } 2 \text { times } \\
\text { a day, for a week }\end{array}$ & 21 \\
\hline 5 & $\begin{array}{c}\text { Amperidaceae } \\
\text { Cissus quadrangularis } \\
\text { English names: } \\
\text { asthisamharaka; } \\
\text { Asthisonhara, Chadhuri, } \\
\text { Chaudhari } \\
\text { Herb }\end{array}$ & $\begin{array}{l}\text { Epripri (Wum), Njol (Bassa) } \\
\text { Ndieh gap (Bamoun), } \\
\text { Ntang-dikun (kom), Ndig } \\
\text { (Kaka); alvarahala, Gadal, } \\
\text { Chimbaral (Fufuldé) }\end{array}$ & Leafy stem & $\begin{array}{c}\text { Secondary } \\
\text { high blood } \\
\text { pressure }\end{array}$ & $\begin{array}{c}\text { Vitamin c/ } \\
\text { Antioxidant }[14,19]\end{array}$ & $\begin{array}{l}\text { Maceration of } 200 \mathrm{~g} \\
\text { of leafy stems finely } \\
\text { cut, in } 2 \mathrm{~L} \text { of water. }\end{array}$ & Oral & $\begin{array}{c}\text { Drink } 250 \mathrm{~mL}, 3 \\
\text { times a day, for } 3 \\
\text { days. }\end{array}$ & 7 \\
\hline
\end{tabular}


Citation: Tsabang N, Yedjou CG, Tchounwou PB (2017) Phytotherapy of High Blood Pressure in Three Phytogeographic Regions of Cameroon Pharm Anal Acta 7: 530. doi: 10.4172/2153-2435.1000530

Page 4 of 7

\begin{tabular}{|c|c|c|c|c|c|c|c|c|c|}
\hline 6 & $\begin{array}{l}\text { Rutaceae Zanthoxylum heitzii } \\
\text { English names: African } \\
\text { satinwood, African stainwood, } \\
\text { white African mahogany } \\
\text { Tree }\end{array}$ & $\begin{array}{c}\text { Bolonais (Baka), Bongo } \\
\text { (Ewondo), Oblong (Fang), } \\
\text { Djouba (Badjoue) }\end{array}$ & Stem bark & & & $\begin{array}{l}\text { Decoction of } 200 \mathrm{~g} \\
\text { of stem bark, for } 15 \\
\mathrm{~min} \text {, in } 2 \mathrm{~L} \text { of water. }\end{array}$ & Oral & $\begin{array}{c}\text { Drink } 250 \mathrm{~mL} \text { of } \\
\text { decoction, } 2 \text { times } \\
\text { daily, for } 5 \text { days. }\end{array}$ & 3 \\
\hline 7 & $\begin{array}{c}\text { Caesalpiniaceae Afzelia } \\
\text { pachyloba } \\
\text { English names: African oak; } \\
\text { African mahogany } \\
\text { Tree }\end{array}$ & $\begin{array}{l}\text { common names "pod } \\
\text { mahogany } \\
\text { Edison fun (Boulou), Njié- } \\
\text { bondondé (Baka) }\end{array}$ & Bark & & & $\begin{array}{l}\text { Decoction of } 200 \mathrm{~g} \text { of } \\
\text { bark in } 3 \mathrm{~L} \text { of water, } \\
\quad \text { for } 15 \mathrm{~min} .\end{array}$ & Oral & $\begin{array}{l}\text { Drink } 200 \mathrm{~mL} \text { of } \\
\text { decoction times } \\
\text { daily, for a week. }\end{array}$ & 6 \\
\hline 8 & $\begin{array}{c}\text { Asteraceae } \\
\text { Bidens pilosa } \\
\text { English names: beggar tick; } \\
\text { bur marigold; cobbler's pegs; } \\
\text { duppy needles; farmer's } \\
\text { friend; needle grass } \\
\text { Herb }\end{array}$ & $\begin{array}{c}\text { Tetseneck, Maleliet } \\
\text { (Yemba-Menoua), Fortah } \\
\text { (Lamso); yiéré, Touwan } \\
\text { (Bamoun), Enjohn missi } \\
\text { (Kaka), Fortar (Nso), Fonta } \\
\text { (Banso), Pihanhua (Bana } \\
\text { Haut-Nkam), Fasomonto- } \\
\text { Comboh (Bakossi), Njimnjim } \\
\text { (Bassa); Ateurri (Boulou), } \\
\text { Biakoua (Féfé-Haut-Nkam), } \\
\text { Ngathabre (Fufulde), Kegis } \\
\text { (Oku), Foseénu (Nkom) } \\
\text { Ntchaquegnê (Medumba- } \\
\text { Ndé), Mfegzoa, Avè-Bikon } \\
\text { (Ewondo), Lilia Mnioc (Batié- } \\
\text { Haut-Plateau); Kio Mnye } \\
\text { (Baham-Haut-Plateau), } \\
\text { Ayebana, Fogue Fogue, } \\
\text { Pougoudou (Yambassa) }\end{array}$ & $\begin{array}{c}\text { Fresh leaves } \\
\text { Dry leaves }\end{array}$ & $\begin{array}{l}\text { Secondary } \\
\text { high blood } \\
\text { pressure }\end{array}$ & $\begin{array}{c}\text { Phytosterin- } \beta / \\
\text { Hypotensive }[16,23]\end{array}$ & $\begin{array}{l}\text { Decoction of } 200 \mathrm{~g} \\
\text { of fresh leaves or } 80 \\
\mathrm{~g} \text { of dry leaves in } 4 \mathrm{~L} \\
\text { of water, for } 20 \mathrm{~min} .\end{array}$ & Oral & $\begin{array}{c}\text { Drink } 250 \mathrm{~mL} \text { of } \\
\text { decoction, } 4 \text { times } \\
\text { a day, for a week } \\
\text { days }\end{array}$ & 8 \\
\hline \multicolumn{10}{|c|}{ Continental rain forests region } \\
\hline 1 & $\begin{array}{c}\text { Phyllanthaceae Phyllanthus } \\
\text { niruri } \\
\text { English names: } \\
\text { Tonebreaker, Seed-Under- } \\
\text { Leaf } \\
\text { Herb }\end{array}$ & & Aerial part & $\begin{array}{c}\text { Essential } \\
\text { high blood } \\
\text { pressure }\end{array}$ & \begin{tabular}{|c|} 
Inhibitor of conversion \\
enzyme (ICE) \\
fonctioning with three \\
substances: ellargic \\
acid, gallic acid and \\
geraniin./hypotensive \\
[17].
\end{tabular} & $\begin{array}{c}\text { Decoction of } 100 \mathrm{~g} \\
\text { of aerial part in } 2 \mathrm{~L} \text { of } \\
\text { water, for } 15 \mathrm{~min}\end{array}$ & Oral & $\begin{array}{c}\text { Drink } 250 \mathrm{~mL} \text { of } \\
\text { decoction, } 2 \text { times } \\
\text { daily, for a week }\end{array}$ & 10 \\
\hline 2 & $\begin{array}{l}\text { Liliaceae } \\
\text { Aloe buttneri } \\
\text { Herb }\end{array}$ & & Bulb & & & \multirow{2}{*}{$\begin{array}{l}\text { Infuse } 200 \mathrm{~g} \text { of bulb } \\
\text { of onion, cut into } \\
\text { small pieces, in } 2 \mathrm{~L} \\
\text { of water, for } 24 \mathrm{~h} \text {. }\end{array}$} & \multirow[b]{2}{*}{ Oral } & \multirow[b]{2}{*}{$\begin{array}{c}\text { Drink } 250 \mathrm{~mL} \\
\text { 'infusion, } 4 \text { times } \\
\text { a day, for a week. }\end{array}$} & 208 \\
\hline 3 & $\begin{array}{c}\text { Aloe barteri } \\
\text { Herb }\end{array}$ & & & & & & & & \\
\hline 4 & $\begin{array}{c}\text { Fabaceae } \\
\text { Mucuna pruriens } \\
\text { English common name: } \\
\text { Cowhage } \\
\text { Herb }\end{array}$ & & Leaves & $\begin{array}{c}\text { Secondary } \\
\text { high blood } \\
\text { pressure }\end{array}$ & $\begin{array}{c}\text { Indolic hydrosoluble } \\
\text { bases/ } \\
\text { Hypocholesterolemiant } \\
{[17,22]}\end{array}$ & $\begin{array}{c}\text { Decoction of } 100 \mathrm{~g} \\
\text { of young leafy stems, } \\
\text { in } 2 \mathrm{~L} \text { of water, for } \\
15 \text { min. }\end{array}$ & Oral & $\begin{array}{c}\text { Drink } 250 \mathrm{~mL} \text { of } \\
\text { decoction, } 3 \text { times } \\
\text { daily, for } 7 \text { days. }\end{array}$ & 4 \\
\hline 5 & $\begin{array}{c}\text { Apocynaceae Voacanga } \\
\text { thouarsii } \\
\text { English name: Wild } \\
\text { Frangipani }\end{array}$ & Etô (Eton) & Bark & $\begin{array}{c}\text { Secondary } \\
\text { high blood } \\
\text { pressure }\end{array}$ & $\begin{array}{c}\text { Voacamine, } \\
\text { Vobtusine, Voacagine; } \\
\text { tabersonine, Voacorine } \\
{[12,13,21,24]}\end{array}$ & $\begin{array}{l}\text { Boil } 200 \mathrm{~g} \text { of bark } \\
\text { in } 4 \mathrm{~L} \text { of water, for } \\
20 \mathrm{~min} \text {. }\end{array}$ & Oral & $\begin{array}{c}\text { Drink } 250 \mathrm{~mL} \text { of } \\
\text { decoction, } 3 \text { times } \\
\text { a day, for a week. }\end{array}$ & 4 \\
\hline 6 & $\begin{array}{l}\text { Rutaceae Zanthoxylum } \\
\text { macrophylla } \\
\text { English African satinwood } \\
\text { Tree }\end{array}$ & $\begin{array}{l}\text { Nleh-rohng (Bafia), Elongo } \\
\text { (New-Balimba) }\end{array}$ & $\begin{array}{l}\text { Fresh } \\
\text { Leaves }\end{array}$ & & & $\begin{array}{c}\text { Infusion of } 50 \mathrm{~g} \text { of } \\
\text { fresh leaves in } 1 \mathrm{~L} \text { of } \\
\text { water, for } 30 \mathrm{~min} .\end{array}$ & Oral & $\begin{array}{c}\text { Drink } 250 \mathrm{~mL} \text { of } \\
\text { infusion } 4 \text { times a } \\
\text { day, for a week. }\end{array}$ & 8 \\
\hline 7 & $\begin{array}{c}\text { Rutaceae } \\
\text { Vepris louisii }\end{array}$ & Tanda (Baka) & Bark & & & $\begin{array}{c}\text { Decoction of } 250 \mathrm{~g} \\
\text { of root bark, in } 6 \mathrm{~L} \text { of } \\
\text { water, for } 25 \mathrm{~min} .\end{array}$ & Oral & $\begin{array}{l}\text { Drink } 250 \mathrm{~mL} \text { of } \\
\text { decoction, } 3 \text { times } \\
\text { daily, for } 5 \text { days. }\end{array}$ & 8 \\
\hline \multicolumn{10}{|c|}{ Guinean and Sudano-Zambezian savannahs region } \\
\hline 1 & $\begin{array}{c}\text { Rubiaceae } \\
\text { Hallea inermis } \\
\text { English name: false abura } \\
\text { Tree }\end{array}$ & $\begin{array}{c}\text { Koli, Harhandelo (Fululdé), } \\
\text { Har (Kotoko), Kabé, Diaye, } \\
\text { Diéya (Haoussa) }\end{array}$ & Bark & \multirow[b]{2}{*}{$\begin{array}{c}\text { Secondary } \\
\text { high blood } \\
\text { pressure }\end{array}$} & \multirow[b]{2}{*}{$\begin{array}{l}\text { Rotundifoline, } \\
\text { rhynchophylline/ } \\
\text { Hypotensive }[12,20]\end{array}$} & $\begin{array}{c}\text { Decoction of } 200 \mathrm{~g} \\
\text { of stem bark in } 3 \mathrm{~L} \text { of } \\
\text { water, for } 20 \mathrm{~min} .\end{array}$ & Oral & $\begin{array}{c}\text { Drink } 250 \mathrm{~mL} \text { of } \\
\text { decoction, } 3 \text { times } \\
\text { a day, for a week. }\end{array}$ & 3 \\
\hline 2 & $\begin{array}{c}\text { Rubiaceae } \\
\text { Hallea stipulosa } \\
\text { English names: poplar, Trade } \\
\text { abura; bahia } \\
\text { Tree }\end{array}$ & $\begin{array}{c}\text { Adjobojan, Afopzam } \\
\text { (Boulou), Ohambé (Bassa), } \\
\text { Elolom (Ewondo), Etok } \\
\text { akpa (Ejagham, Balong and } \\
\text { Oroko) }\end{array}$ & Stem bark & & & $\begin{array}{c}\text { Decoction of } 200 \mathrm{~g} \\
\text { of stem bark in } 4 \mathrm{~L} \text { of } \\
\text { water, for } 30 \mathrm{mn} \text {. }\end{array}$ & Oral & $\begin{array}{c}\text { Drink } 250 \mathrm{~mL} \text { of } \\
\text { decoction, } 3 \text { times } \\
\text { daily, for } 7 \text { days. }\end{array}$ & 7 \\
\hline
\end{tabular}


Citation: Tsabang N, Yedjou CG, Tchounwou PB (2017) Phytotherapy of High Blood Pressure in Three Phytogeographic Regions of Cameroon. Pharm Anal Acta 7: 530. doi: 10.4172/2153-2435.1000530

Page 5 of 7

\begin{tabular}{|c|c|c|c|c|c|c|c|c|c|}
\hline 3 & $\begin{array}{c}\text { Liliaceae } \\
\text { Allium sativum } \\
\text { English name: Garlic } \\
\text { Herb }\end{array}$ & Albacce, Albasarre (Fufuldé) & $\begin{array}{l}\text { Stem } \\
\text { Bulb }\end{array}$ & $\begin{array}{c}\text { Secondary } \\
\text { high blood } \\
\text { pressure }\end{array}$ & $\begin{array}{l}\text { Organic sulfuric/ } \\
\text { Peripheral } \\
\text { vasodilatation [14] } \\
\text { Calcium channel } \\
\text { inhibitor }\end{array}$ & $\begin{array}{l}\text { Decoction of } 100 \mathrm{~g} \\
\text { of stem and } 100 \mathrm{~g} \\
\text { of cut bulb in } 4 \mathrm{~L} \text { of } \\
\text { water, for } 15 \mathrm{~min} .\end{array}$ & Oral & $\begin{array}{l}\text { Drink } 250 \mathrm{~mL} \text { of } \\
\text { decoction, } 2 \text { times } \\
\text { daily, for a week. }\end{array}$ & 8 \\
\hline 4 & $\begin{array}{c}\text { Rutaceae } \\
\text { Vepris heterophylla } \\
\text { English. name: Candlewood }\end{array}$ & $\begin{array}{l}\text { Kinkéliba, Kinkéliba de } \\
\text { Kita, Jamba, boutoumbali } \\
\text { (Arabes Choa) }\end{array}$ & Fresh leaves & & & $\begin{array}{l}\text { Boil } 100 \mathrm{~g} \text { of fresh } \\
\text { leaves in } 3 \mathrm{~L} \text { of } \\
\text { water, in } 30 \mathrm{mn} .\end{array}$ & Oral & $\begin{array}{c}\text { Drink } 250 \mathrm{~mL} \text { of } \\
\text { decoction, } 3 \text { times } \\
\text { a day. }\end{array}$ & 2 \\
\hline 5 & $\begin{array}{c}\text { Mimosaceae Albizia coriaria } \\
\text { English names: worm-bark } \\
\text { false-thorn, worm-cure albizia, } \\
\text { cherry-blossom } \\
\text { Tree }\end{array}$ & $\begin{array}{l}\text { Sanda, Tolo (Baya), } \\
\text { Pâssour (Bamoun) }\end{array}$ & Stem bark & & & $\begin{array}{c}\text { Maintain in ebullition } \\
100 \mathrm{~g} \text { of stem bark } \\
\text { in } 2 \mathrm{~L} \text { of water, for } \\
25 \mathrm{~nm} .\end{array}$ & Oral & $\begin{array}{c}\text { Drink } 250 \mathrm{~mL} \text { of } \\
\text { decoction, } 4 \text { times } \\
\text { a day. }\end{array}$ & 6 \\
\hline 6 & $\begin{array}{c}\text { Caesalpiniaceae Senna } \\
\text { occidentalis Englis name: } \\
\text { Mamatasba } \\
\text { herb }\end{array}$ & $\begin{array}{l}\text { (Fufuldé); Sangatasha } \\
\text { (Eton); Sanga (Ewondo), } \\
\text { Ngasila (Baya) common } \\
\text { name: Coffee weed }\end{array}$ & leaves & $\begin{array}{c}\text { Secondary } \\
\text { high blood } \\
\text { pressure }\end{array}$ & \begin{tabular}{|} 
Leaf extract/ \\
Reducing blood \\
pressure by inhibiting \\
$\mathrm{Ca}^{2+}$ influx through \\
receptor-operated \\
channel and voltage- \\
sensitive channel [20], \\
relaxant effect on the \\
aortic rings [20].
\end{tabular} & $\begin{array}{c}\text { 1-Decoction of a } \\
\text { teaspoon of powder } \\
\text { of leaves, in } 200 \mathrm{~mL} \\
\text { of water, for } 10 \mathrm{~min} . \\
\text { 2-consumption of } \\
\text { young }\end{array}$ & Oral & $\begin{array}{l}\text { Take a teaspoon } \\
\text { in the morning, } \\
\text { mi-day and } \\
\text { evening, for } 7 \\
\text { days. } \\
\text { 2-Eat the young } \\
\text { leaves like } \\
\text { vegetable. }\end{array}$ & 7 \\
\hline 7 & $\begin{array}{l}\text { Caesalpiniaceae Afzelia } \\
\text { africana } \\
\text { English names: African oak; } \\
\text { African mahogany } \\
\text { Tree }\end{array}$ & $\begin{array}{c}\text { Guéla (Baya); Ekan (Eton), } \\
\text { Boking (Douala) }\end{array}$ & Bark & & & $\begin{array}{c}\text { Macearation of } 300 \mathrm{~g} \\
\text { of bark in } 6 \mathrm{~L} .\end{array}$ & Oral & $\begin{array}{l}\text { Drink } 250 \mathrm{~mL} \text { of } \\
\text { macerate, } 4 \text { times } \\
\text { a day, for } 7 \text { days. }\end{array}$ & 4 \\
\hline 8 & $\begin{array}{c}\text { Ulmaceae } \\
\text { Celtis integrifolia } \\
\text { English names: nettle tree, } \\
\text { African nettle tree: African } \\
\text { false elm; hackberry } \\
\text { Tree }\end{array}$ & Ganki, Jukigenki (Fufuldé) & Bark & & & $\begin{array}{l}\text { Decoction in } 4 \mathrm{~L} \text { of } \\
\text { water, } 250 \mathrm{~g} \text { of root } \\
\text { bark, in } 30 \mathrm{~min} .\end{array}$ & Oral & $\begin{array}{l}\text { Drink } 250 \mathrm{~mL} \text { of } \\
\text { decoction, } 4 \text { times } \\
\text { daily, for a week. }\end{array}$ & 4 \\
\hline 9 & $\begin{array}{c}\text { Rhamnaceae Ziziphus } \\
\text { mauritiana } \\
\text { English Names: Indian } \\
\text { Jujube, ber, Chinee apple, } \\
\text { jujube, Indian plum. Kannada } \\
\text { Shurb }\end{array}$ & $\begin{array}{c}\text { Fi (Tokoto), Magaria, } \\
\text { Mgariar, Koura (Haoussa), } \\
\text { Déré (Toupouri), Embaé } \\
\text { (Moundang), Verkasa } \\
\text { (Mafa),Dovasené (Kapsiki), } \\
\text { Gulumjaabi (Fufuldé }\end{array}$ & Fruit & $\begin{array}{l}\text { Secondary } \\
\text { high blood } \\
\text { pressure }\end{array}$ & $\begin{array}{c}\text { Vitamin } \mathrm{cl} \\
\text { Antioxidant }[17,19,24]\end{array}$ & Eating of fruits & Oral & $\begin{array}{l}\text { Eat } 3 \text { fruits per } \\
\text { day, for a week. } \\
\text { Root is toxic in } \\
\text { strong dosage }\end{array}$ & 6 \\
\hline 10 & $\begin{array}{c}\text { Rutaceae Zanthoxylum } \\
\text { zanthoxyloides, } \\
\text { English names: prickly shrub } \\
\text { or low-branching shrubby } \\
\text { Tree }\end{array}$ & Gah-tchou (Bamiléké) & Stem bark & & & $\begin{array}{c}\text { Decoction of } 300 \mathrm{~g} \text { of } \\
\text { stem bark, in } 2 \mathrm{~L} \text { of } \\
\text { water, for } 20 \mathrm{~min} .\end{array}$ & Oral & $\begin{array}{c}\text { Drink } 250 \mathrm{~mL} \text { of } \\
\text { decoction, } 3 \text { times } \\
\text { a day, a week. }\end{array}$ & 6 \\
\hline 11 & $\begin{array}{c}\text { Combretaceae Guiera } \\
\text { senegalensis } \\
\text { English name: sabara } \\
\text { Shurb }\end{array}$ & $\begin{array}{c}\text { Gelloki, Guélloki (Fufuldé), } \\
\text { Sabara, Schabala } \\
\text { (Haoussa), Abes, Rabbes, } \\
\text { Ribes (Arabes-Choa), Kose } \\
\text { (Kotoko), Waburobero } \\
\text { (Fali), Fullafull (Massa), } \\
\text { Ha'fay (Moundang), Fur, furi } \\
\text { (Toupouri) }\end{array}$ & Leaves & & & $\begin{array}{l}\text { Infusion of } 100 \mathrm{~g} \\
\text { of leaves in } 3 \mathrm{~L} \text { of } \\
\text { water, for at least } \\
2 \mathrm{~h} .\end{array}$ & Oral & $\begin{array}{c}\text { Drink } 250 \mathrm{~mL} \text { of } \\
\text { infusion, } 3 \text { times a } \\
\text { day, for } 5 \text { days. }\end{array}$ & 6 \\
\hline 12 & $\begin{array}{c}\text { Fabaceae Pterocarpus } \\
\text { santalioides } \\
\text { Shurb }\end{array}$ & $\begin{array}{l}\text { Bolota (Baya), Mâdobihia } \\
\text { (Haoussa) }\end{array}$ & Stem bark & & $\begin{array}{l}\text { bioactive substances } \\
\text { (flavonoids, tannins, } \\
\text { saponins, phenols } \\
\text { Polyphenol)[28] }\end{array}$ & $\begin{array}{c}\text { Decoction of } 250 \mathrm{~g} \text { of } \\
\text { stem bark, in } 5 \mathrm{~L} \text { of } \\
\text { water, for } 40 \mathrm{mn} \text {, }\end{array}$ & Oral & $\begin{array}{c}\text { Drink } 250 \mathrm{~mL} \text { of } \\
\text { decoction, } 3 \text { times } \\
\text { a day, for } 5 \text { days. }\end{array}$ & 4 \\
\hline 13 & $\begin{array}{c}\text { Balanitaceae Balanites } \\
\text { aegyptiaca } \\
\text { Common. English names: } \\
\text { soapberry tree; thorn tree; } \\
\text { desert date } \\
\text { Shurb }\end{array}$ & Adoua (Fulbés) & Fruits & $\begin{array}{c}\text { Secondary } \\
\text { high blood } \\
\text { pressure }\end{array}$ & $\begin{array}{c}\text { Fruits/ } \\
\text { Hypocholesterolemiant } \\
\text { Vasodilatator [17] }\end{array}$ & Eating & Oral & $\begin{array}{l}\text { Eat three fruits } \\
\text { a day, for two } \\
\text { weeks }\end{array}$ & 10 \\
\hline \multicolumn{10}{|c|}{ Common in the three phytogeographic regions } \\
\hline 1 & $\begin{array}{c}\text { Annonaceae Annona muricata } \\
\text { English names: prickly } \\
\text { custard apple, soursop } \\
\text { Shurb }\end{array}$ & $\begin{array}{l}\text { Common name: Prickly } \\
\text { Custard apple }\end{array}$ & Leaves & \begin{tabular}{|c|} 
Secondary \\
high blood \\
pressure
\end{tabular} & $\begin{array}{l}\text { Leaf extract/ } \\
\text { Decreasing the } \\
\text { peripheral vascular } \\
\text { resistance [16] }\end{array}$ & $\begin{array}{l}\text { Infusion of } 100 \mathrm{~g} \\
\text { of leaves in } 3 \mathrm{~L} \text { of } \\
\text { water, for at least } \\
2 \mathrm{~h} \text {. }\end{array}$ & Oral & $\begin{array}{c}\text { Drink } 250 \mathrm{~mL} \text { of } \\
\text { infusion, } 3 \text { times a } \\
\text { day, for } 5 \text { days. }\end{array}$ & 13 \\
\hline 2 & $\begin{array}{c}\text { Moringaceae Moringa oleifera } \\
\text { English name: Drumstick } \\
\text { plant } \\
\text { Shurb }\end{array}$ & Common name: Murungai & Leaves & & $\begin{array}{c}\text { Thiocarbamate } \\
\text { and isothiocyanate } \\
\text { fractions/ } \\
\text { Fall in systolic, } \\
\text { diastolic, and mean } \\
\text { blood pressure in } \\
\text { a dose-dependent } \\
\text { manner [22] }\end{array}$ & $\begin{array}{c}\text { Boil } 50 \mathrm{~g} \text { of leaves } \\
\text { in } 1 \mathrm{~L} \text { of water, for } \\
15 \mathrm{mn} \text {. }\end{array}$ & Oral & $\begin{array}{l}\text { Drink } 250 \mathrm{~mL} \text { of } \\
\text { decoction, } 3 \text { times } \\
\text { per day, for } 3 \\
\text { days. }\end{array}$ & 280 \\
\hline
\end{tabular}


Citation: Tsabang N, Yedjou CG, Tchounwou PB (2017) Phytotherapy of High Blood Pressure in Three Phytogeographic Regions of Cameroon Pharm Anal Acta 7: 530. doi: 10.4172/2153-2435.1000530

Page 6 of 7

\begin{tabular}{|c|c|c|c|c|c|c|c|c|c|}
\hline 3 & $\begin{array}{c}\text { Cecropiaceae Musanga } \\
\text { cecropiodes } \\
\text { English names: African } \\
\text { corkwood tree or umbrella } \\
\text { tree } \\
\text { Tree }\end{array}$ & $\begin{array}{l}\text { Common name: Umbrella } \\
\text { tree, Cork Wood }\end{array}$ & Stem bark & $\begin{array}{c}\text { Secondary } \\
\text { high blood } \\
\text { pressure }\end{array}$ & $\begin{array}{c}\text { The latex and the } \\
\text { leaves aqueous } \\
\text { extract } \\
\text { Vasorelaxant agent } \\
\text { The water extract } \\
\text { of the stem bark/ } \\
\text { reduction in mean } \\
\text { arterial blood } \\
\text { pressure, which fell } \\
\text { by } 4.51 \pm 0.5 \mathrm{mmHg} \\
\text { at the dose of } 10 \mathrm{mg} / \\
\mathrm{kg} \text { and } 65.23 \pm 6.28 \\
\mathrm{mmHg} \text { at } 40 \mathrm{mg} / \mathrm{kg} \\
\text { dose }[26,27] .\end{array}$ & $\begin{array}{c}\text { Decoction of } 1.5 \mathrm{~g} \text { of } \\
\text { stem bark per } \mathrm{kg} \text { of } \\
\text { body weight in } 3 \mathrm{~L} \text { of } \\
\text { water for } 15 \mathrm{~min} .\end{array}$ & Oral & $\begin{array}{c}\text { Take } 250 \mathrm{~mL} \\
\text { of decoction, } 2 \\
\text { times a day, for } \\
5 \text { days. The long } \\
\text { time use and the } \\
\text { strong doses can } \\
\text { provoke gastric } \\
\text { ulcers (12). }\end{array}$ & 18 \\
\hline & $\begin{array}{c}\text { Number of species by } \\
\text { morphology } \\
\text { Total: } 28(100 \%) \\
\text { Trees: } 9(32 \%) \\
\text { Herb: } 10(36 \%) \\
\text { Shurb: } 9(32 \%)\end{array}$ & & $\begin{array}{c}\text { Parts of the } \\
\text { plants used } \\
\text { Total: } 42 \\
(100 \%) \\
\text { Leaves: } 18 \\
(43 \%) \\
\text { Bark: } 14 \\
(33 \%) \\
\text { Aerial part: } 5 \\
(12 \%) \\
\text { Fruit: } 2(5 \%) \\
\text { Bulb: } 2(5 \%) \\
\text { Stem: } 1(2 \%)\end{array}$ & & & $\begin{array}{c}\text { Number of times } \\
\text { that each modes } \\
\text { of preparation } \\
\text { appeared } \\
\text { Total: } 28(100 \%) \\
\text { Decoction: } 19(68 \%) \\
\text { Maceration: } 3(11 \%) \\
\text { Infusion: } 5(18 \%) \\
\text { Consumption: } 1(3 \%)\end{array}$ & $\begin{array}{l}\text { Oral: } 28 \\
(100 \%)\end{array}$ & $\begin{array}{c}\text { Number of times } \\
\text { that an ethno } \\
\text { pharmacological } \\
\text { preparation time } \\
\text { appeared: } \\
\text { Total: } 19(100 \%) \\
15 \mathrm{mn}: 8(42 \%) \\
20 \mathrm{mn}: 4(21 \%) \\
25 \mathrm{mn}: 2(11 \%) \\
30 \mathrm{mn}: 4(21 \%) \\
2 \mathrm{~h}: 1(5 \%) \\
\text { Number of times } \\
\text { that a duration } \\
\text { of treatment } \\
\text { appeared: } \\
\text { Total: } 29(100 \%) \\
1 \text { day: } 1(3 \%) \\
3 \text { days: } 2(2,7 \%) \\
5 \text { days: } 7(24 \%)\end{array}$ & $\begin{array}{c}\text { Number of } \\
\text { times that a } \\
\text { frequency } \\
\text { appeared: } \\
\text { Total: } 27 \\
(100 \%) \\
280: 1(4 \%) \\
208: 1(4 \%) \\
6: 6(23 \%) \\
4: 5(19 \%) \\
8: 2(7 \%) \\
7: 3(11 \%) \\
18: 2(7 \%) \\
10: 2(7 \%) \\
3: 2(7 \%) \\
13: 1(4 \%) \\
5: 1(4 \%) \\
21: 1(4 \%)\end{array}$ \\
\hline
\end{tabular}

Table 2: Ethno pharmacological methods of preparation and administration of herbal remedies.

an important antihypertensive plant due to its hypotensive actions, thus can be strongly recommended to traditional healers. The uncontrolled use of a hypotensive plant can provoke a fatal low blood pressure in hypertensive patients. Therefore the use of hypotensive plants needs to be controlled by physician or by a personal verification using a blood pressure monitor.

\section{Acknowledgment}

Thanks are expressed to local therapists, householders and other interviewees met in the field which have collaborated to the realization of this work to Bioresources Development and Conservation Programme-Cameroon for the training courses that we receive on field ethnobiology and to Professor Koueke Paul, retired Professor of Faculty of Medicine and Biomedical Sciences, University of Yaoundé 1 for precious supervision of this work.

\section{References}

1. (2000) A.F.D (Association française des Diabétiques). Une épidémie est annoncée. Equilibre 214: 8-10.

2. Mbanya JCN, Minkoulou EM, Salah JN, Balkau B (1998) The Prevalence of hypertension in rural and urban Cameroon. Int J Epidemiol 27: 181-185.

3. Grimaldi A, Hartemann-Heurtier A (1996) Diabète et Génétique. Collection 'Diabète' Edité par Phases, Paris, p: 48.

4. Tsabang N, Ngah N, Estella FT, Agbor GA (2016) Herbal Medicine and Treatment of Diabetes in Africa: Case Study in Cameroon. Diabetes Case Rep 1: 112.

5. Tsabang N (2008) Etude ethnobotanique des plantes à vertus antidiabétiques et/ou antihypertensive au Cameroun. Université de Yaoundé I, p: 319

6. Saganuwan, Saganuwan A (2010) Some medicinal plants of Arabian Pennisul. J Med Plant Res 4: 766-788.

7. Asase A, OtengYeboah AA, Odamtten GT, Simmonds MSJ (2005) Ethnobotanical study of some Ghanaian antimalarial plants. J Ethnopharmacol 99: 273-279

8. Asase A, Oppong-Mensah G (2009) Traditional antimalarial phytotherapy remedies in herbal markets in southern Ghana. J Ethnopharmacol 126: 492-499.
9. Tabuti JRS (2008) Herbal medicines used in the treatment of malaria in Budiope County, Uganda. J Ethnopharmacol 116: 33-42.

10. Nguta JM, Mbaria JM, Gakuya DW, Gathumbi PK (2010) Antimalarial herbal remedies of Msambweni, Kenya. J Ethnopharmacol 128: 424-432.

11. Tsabang N, Nkongmeneck BA, Zapfact L, Nzooh Dongmo Z, Nguenang GM, et al. (2001) Inventaire des plantes à vertus antidiabétiques dans la région de Yaoundé au Cameroun. Revue Méd Pharm Afr Paris 15: 87-94.

12. Paris RR, Moyse H (1971) Précis de matières médicales: collection de précis de pharmacie, Pharmacognosie spéciale, dicotylédone (suite) gamopétales. Masson et Cie. Editeurs Paris Vie. Tome 3: 509.

13. Bep OB (1986) Medicinal plants in Tropical West-Africa. Cambridge University Press. Cambridge, NY, USA, p: 375.

14. CIPCRE (2000) Connaissez-vous les plantes Médicinales ? Rapport de recherche. Cercle International pour la Promotion de la création (CIPCRE). ONG, Bafoussam.

15. Claudia MNE, Fomekong, Inès DG, Dagobert T, Dongo E, et al. (2007) Effect of Aqueous and Methanol/Methylene-Chloride Extracts of Laportea ovalifolia (Urticaceae) on Blood Glucose Level in Rats. Pharmacologyonline 3: 105-118.

16. Hasrat JA, Pieters L, Vlietinck AJ (2004) Medicinal plants in Suriname: hypotensive effect of Gossypium barbadense. J Pharm Pharmacol 56: 381387.

17. Pousset JL (1989) Plantes Médicinales Africaines. Utilisation pratique. TOME I. Ellipses, Edition Marketing, Paris, p: 170.

18. Volak J, Etodola J (1997) Plantes médicinales. Edition 'La nature à livre ouvert (Elogan). Librairie Grund, Paris, p: 90.

19. Rah M (1997) Pourquoi les animaux n'ont pas d'infarctus hommes si? La découverte qui va mener à l'éradication des maladies cardiaques. Le plus important programme de santé cardiovasculaire. MR publishing, San Francisco, CA 94102, USA, p: 270.

20. Ajagbonna OP, Mojiminiyi FBO, Sofola OA (2001) Relaxant effects of the aqueous leaf extract of Cassia occidentalis on rat aortic rings. Afr $\mathrm{J}$ Biomed Res 4: 127-129.

21. Bouquet A, Debray M (1974) Travaux et Documents de l'office de la Recherche 
Citation: Tsabang N, Yedjou CG, Tchounwou PB (2017) Phytotherapy of High Blood Pressure in Three Phytogeographic Regions of Cameroon. Pharm Anal Acta 7: 530. doi: 10.4172/2153-2435.1000530

Scientifique d'Outre-Mer (ORSTOM), plantes médicinales de la Côte-d'Ivoire, Paris, p: 220

22. Faizi S, Siddiqui BS, Saleem R, Aftab K, Shaheen F, et al. (1998) Hypotensive constituents from the pods of Moringa oleifera. Planta Med 64: 225-228.

23. Tsabang N, Nkongmeneck BA, Nguenang GM, Fongnzossie E, Koueke $P$, et al (2005) Médecine traditionnelle. Une méthode d'identification des diabétiques et des plantes pouvant améliorer leur état de santé. Revue Cameroon Ethnobotanique Network 1: 53-62.

24. Kerharo J, Adam G (1974) La pharmacopée Sénégalaise traditionnelle. Plantes médicinales et toxiques. Editions Vigot frère, Paris, p: 1011.
25. Dimo T, Nguelefack BT, Dongo E, Rakotonirina A, Rakotonirina SV (1999) Effets hypotensifs de l'extrait au méthanol de Bidens pilosa L. chez les rats hypertendus. Pharmacologie, pp: 322-329.

26. Kamanyi A, Bopelet M, Aloamaka CP, Obiefuna PC, Ebeigbe AB (1991) Endothelium-dependent rat aortic relaxation to the aqueous leaf extract of Musanga cecropioides. J Ethnopharmacol 34: 283-286.

27. Owolabi OJ, Ayinde BA, Nworgu ZA, Ogbonna OO (2010) Antidiarrheal evaluation of the ethanol extract of Musanga cecropioides stem bark. Met Find Exp Clin Pharmacol 32: 407-411.

28. Eze SO, Cornelius C, Okereke H (2012) Phytochemical and Antimicrobia Analysis of the Stem Bark of Pterocarpus santalinoides, (Nturu Ukpa). Asian J Nat Appl Sci 1: 26-32. 